\title{
Character Formation Based on North Sumatra Local Wisdom Through Orchestral Learning in Music Education Study Program, Universitas Negeri Medan
}

\author{
Adina S Sembiring ${ }^{1}$, Uyuni Widiastuti ${ }^{2}$, Octaviana Tobing ${ }^{3}$, Esra PT Siburian ${ }^{4}$, Hendy $^{6}$ \\ Obed Sembiring ${ }^{5}$, Ewin Johan Sembiring ${ }^{6}$ \\ 1, 2, 3, 4, 5, 6 Music Education Study Program, Faculty Languages and Arts, Universitas Negeri Medan \\ adina_matheny@yahoo.com
}

\begin{abstract}
The objectives of this study are to: (1) Producing character building based on North Sumatra local wisdom through orchestral learning in Music Education Study Program, Unimed; (2) Producing orchestral learning that can shape the character of students in the Music Education Study Program; (3) Producing characters that are formed through orchestral learning in Music Education Study Program, Unimed. It is expected that the existence of research on the topic of orchestral learning in Music Education Study Program, Unimed can shape character based on local wisdom in North Sumatra.
\end{abstract}

Keywords: Character building; local wisdom; orchestra.

\section{Introduction}

The School Music Ensemble course is one of the subjects in Music Education Study Program at Faculty of Languages and Arts, Universitas Negeri Medan. This course appears in each odd and even semester, where students will choose one of three types of School Music Ensembles, namely Orchestra, Traditional Music and Marching Band. The aim of the School Music Ensemble course in Music Education Study Program Unimed is for students to fulfill extracurricular teaching in secondary schools (junior and senior high schools / vocational high schools). Data obtained from students, there are 30\% of students who have taught extracurricular at school before the student completes his studies at the Music Education Study Program. This shows that the course of the School Music Ensemble can be used as a development of knowledge gained by students during lectures and as income generation for students.

Although the School Music Ensemble course is the chosen course in Music Education Study Program, it turns out that many students choose this course to be chosen (around 70 people). This shows that this course is really in demand by students of Music Education Study Program Unimed, because the Music Education Study Program Unimed is the only orchestra in similar Universities in North Sumatra (Universitas Sumatera Utara and HKBP Nomennsen University) .

Lots of knowledge gained by students in studying the Orchestra, ranging from music theory, the practice of playing musical instruments, and the characters that exist in orchestral learning, such as: discipline, cooperation, self-control, responsibility and others. This character can be inherited from each student, can also be formed through Orchestral learning. In forming these characters can be a better character and can also be a bad character.

Students who study in Music Education Study Program mostly come from tribes in North Sumatra, such as Karo tribe, Toba Batak tribe, Batak, Simalungun, Nias, Malay, Pakpak Barat / Dairi, and others. Each tribe certainly has its own characteristics which are seen from their character or character in themselves. The characters of each tribe in North Sumatra are good and some are bad, for example: the Toba Batak tribe has a loud voice character, Karo Batak tribe has a confident character, Nias tribe has a stubborn character, and others. The tribal 
characters in North Sumatra that are owned by students certainly shape the better students, the more the value of the characters will increase even the emergence of new characters. The emergence of character formation is caused by the learning of the Orchestra which is carried out in Music Education Study Program, because in the learning of the Orchestra it will indirectly shape the character of the student based on the ethnicity inherent in the student.

In the context of character building based on local wisdom of North Sumatra to students, of course it can be done with Orchestral learning. Therefore, researchers are encouraged to conduct research that focuses on Character Formation Based on North Sumatra Local Wisdom Through Orchestral Learning in Music Education Study Program, Universitas Negeri Medan. The objectives of this study are (1) To produce character building based on North Sumatra's local wisdom through orchestral learning in the Unimed Music Education Study Program; (2) To produce orchestral learning that can shape the character of students in the Music Education Study Program; (3) To Produce characters that are formed through orchestral learning in Music Education Study Program Unimed.

Character is the attitude and way of thinking, behaving and interacting as a characteristic of an individual in life, acting and working together, both within the scope of the family, community and nation. Character will be a part of one's identity so that it can be a good identity or personality. According to Doni Kusuma (2007: 67), character is a characteristic, style, trait, or even a personal catastrophe that comes from the formation or even the forging obtained from the surrounding environment. A person's personality is formed in the process of life through a number of ethical values they have, in the form of thought patterns, attitudes and behavior as personalities, the character has presented the whole person.

Character that is often referred to as personality is the accumulation of systematic values that underlie a person's thoughts, attitudes and behavior. There are good personalities and bad personalities. Individual tangible character in a person's behavior, but in essence it is a living value system in a community. There are values that regulate honesty, politeness, justice and so on even though honesty is seen in one's behavior.

Character is a combination of behavior (behavior) with personality, thus the character can be related to behavior and can also be related to personality. If the character is related to the treatment of someone who is honest, polite, responsible, caring, hard working and so on, then the character is called behavior. If the character is related to the behavior of someone who follows the moral rules and values that apply then the character is called personality.

The term character is actually neutral, negative or positive, bad or even good. The character referred to here is a good character called the formation or education of good or positive character, Sibarani (2012: 158). There are 15 types of good ethical characters that are grouped into four groups according to their hierarchy in character building:

a. First group:

- Trusted

- Honest and fair

- Courtesy and respect

- Self control

- To be responsible

- Committed 
b. Second group:

- Get along well and love peace

- Good citizen

- Tolerant

c. Third group

- Caring and compassion

- Firm

- Establishment and integration

- Friendly and communicative

d. Fourth Group

- Democratic

- Reward achievements

- Positive thinking

- Grateful

- Nationalism

In derivational terms, local wisdom consists of two words, namely wisdom and local. So that local wisdom can be understood as local ideas and knowledge that are wise, full of wisdom, good value and virtuous that are owned, guided and carried out by members of the community both from ethnicity-based cultures and those from geographic cultures.

Local wisdom is the wisdom or original knowledge of a community that comes from the noble value of cultural traditions to regulate the order of people's lives. Local wisdom can also be defined as local cultural values that can be utilized to regulate the order of people's lives wisely or wisely. Local wisdom belongs to the community whose attitude and personality are mature to be able to develop local potential and resources in making changes for the better. According to Apriyanto (2008: 59) local wisdom is a variety of values that are created, developed and maintained by the people who guide them in their lives.

Local wisdom comes from cultural values that can still be applied and used wisely in the present both cultural values for the creation of peace and cultural values for improving welfare. Local wisdom includes local customs, local norms, local knowledge, local skills, local resources, local social processes, local institutions, and local beauty. If local wisdom is extracted from an oral tradition or cultural tradition and applied to the younger generation, it will build character in creating peace and improving the welfare of the community.

According to Sibarani (2012: 89) character is a form of original knowledge in the community that comes from the noble values of the local community's culture to regulate the order of people's lives. Formation of character based on local wisdom means the development of character, personality and behavior that loves welfare and peace. Love of prosperity based on local wisdom is called work ethic, while peace love based on local wisdom is called ethics of kindness. Formation of character based on local wisdom will produce human resources with good work ethics. People who work ethically and ethically are called wise characters. Formation of character based on local wisdom seeks to shape one's character by applying cultural values contained in the nation's cultural traditions. The formation of this character will produce characters that are accepted in the community and in accordance with the needs of the nation.

Orchestra is a combination of a large number of music players (Banoe: 2003: 311). Orchestra is played in large numbers with a variety of musical instruments. Orchestra is a group 
of musicians who play musical instruments together. Orchestras can be categorized into several types, including:

a. Symphony Orchestra

Symphony Orchestra is a large standard orchestra known since the 19th century that is capable or qualified to play symphonic works. A complete symphony orchestra with a greater number of musicians playing all kinds of musical instruments both beaten, swiped and blown.

b. Chamber Orchestra

Chamber Orchestra is a small-size orchestra with a limited number of players.

c. String Orchestra

String Orchestra is an orchestra unit consisting of a number of stringed instrument players including Violin, viola, cello, and contra bass.

d. Theater Orchestra

Theater Orchestra is a kind of symphonic music unit by involving a combo-band saxophone instrument.

e. Philharmonic Orchestra

The Philharmonic Orchestra is a complete orchestra which is an extension of the use of a variety of musical instruments compared to a symphony orchestra with limited musical instruments; is a new style in the formation of symphonic orchestra formations.

f. Cosmopolitant Orchestra

Cosmopolitant Orchestra is a complete orchestra that covers a wide range of possibilities for both the symphonic orchestra as its core and the variety of traditional musical instruments.

\section{Research Methods}

This study uses a qualitative thinking framework since the process of data collection, data analysis to the model of application of research results. The implementation of this qualitative research is guided by the following stages: data collection carried out by observation, recording, interviewing and recording; data reduction (data reduction) is done by setting selected data as data to be analyzed; data display (data presentation) is a part that explains data in text or chart form; Conclusion drawing / verification is part of drawing conclusions and verification of research findings, Miles and Huberman (1984).

Data collection techniques in this study is to use closed and open interviews, can provide unlimited and in-depth information from various perspectives that can be in the form of transcripts and stored in text files. Observations are made to obtain data in research that requires careful listening and careful attention to detail in what is seen. Observations are generally in the form of handwriting. Audio recordings are carried out in conducting interviews that are made with audio recordings. Capturing the essence of the conversation requires carefulness and the experience of someone who conducted the interview, so that it can be used to explore the contents of the interview more fully when data processing is done. Video recordings in research are often made in the form of video recordings to complete the data. Video recording can be used to dig deeper into the video content when data processing is done. Data from a book, which comes from certain page data from a book. Data from the pages of the book can be used in data processing along with other data. Data from the web that comes from the pages of a website. Like data from books, data from web pages can be used in processing data with other data. 
Qualitative research uses various data collection techniques and is carried out continuously until the data is saturated. This study uses qualitative data analysis techniques, where the process of finding data through interviews, observations and other materials is arranged systematically. After the data collected from the results of data collection, the writer needs to work on the data by analyzing existing data. Furthermore, the results of data analysis conducted by the author are arranged in such a way as a written report in the form of scientific work.

\section{Discussion}

The orchestra course is one of the practical courses in Music Education Study Program Unimed which is part of the School Music Ensemble course (orchestra, traditional music, marching band). Student orchestra courses must be taken by students in $5^{\text {th }}$ semester after graduating from selected instrument courses (guitar, piano, vocals, wind, string, percussion). Students will play according to the chosen instrument taken from $1^{\text {st }}$ semester to $4^{\text {th }}$ semester. Even though the orchestral course has 3 credits, the reality is that in class students study more than 3 credits, because of the large amount of time that must be prepared before learning begins, such as the preparation of space and equipment for lectures, orchestral lectures and the improvement of space and equipment used in orchestral courses Therefore, learning orchestral courses is carried out three times a week namely Monday, Wednesday and Friday from 14.00 WIB until $20.00 \mathrm{WIB}$. The impact of the intensity of regular course learning produces quality learning, this can be seen from the course products produced in the Even semester 2018/2019 students can make an orchestra performance by displaying various regional songs from Sumatra Island (Padang, Aceh, Riau and North Sumatra). The audience who attended the music performance consisted of various groups such as students, students, artists, arts practitioners and so on, this shows the success of the orchestra course so that the performance is scheduled every year to perform orchestras.

From the data obtained in Music Education Study Program, most of the students who took orchestra courses $(80 \%)$ came from North Sumatra, in addition from Riau, Aceh, Batam, Riau Islands. The data shows that students who take orchestra courses have different cultures and characteristics based on their respective ethnic groups. For more details, the origins of students can be seen in the following table:

Table 1. Violin I

\begin{tabular}{|c|l|l|}
\hline No. Name & \multicolumn{1}{|c|}{ Ethnic } \\
\hline 1 & Petra Marsihar Lbn.Tobing & Batak Toba \\
\hline 2 & Nurul Tri Agustini & Batak Pak-Pak \\
\hline 3. & Suci Maulidya & Melayu \\
\hline 4. & Jeremia Munthe & Batak Toba \\
\hline 5. & Serin Purba & Simalungun \\
\hline 6. & Ruth Miocta Pasaribu & Angkola \\
\hline 7. & Cindy Serafim Silitonga & Batak Toba \\
\hline 8. & Angelina Sipahutar & Batak Toba \\
\hline 9. & Indiswara & Bataktoba \\
\hline 10. & Prasetyo Bagaskara & Jawa \\
\hline 11. & Annisa Putri & Jawa \\
\hline
\end{tabular}




\begin{tabular}{|c|l|l|}
\hline 12. & Dita Syafhira & Jawa \\
\hline 13. & Luthfia Nazwa & Padang \\
\hline 14. & Chairunna Raisa Mariz & Jawa \\
\hline
\end{tabular}

Table 2. Violin II

\begin{tabular}{|c|l|l|}
\hline No. & \multicolumn{1}{|c|}{ Name } & \multicolumn{1}{c|}{ Ethnic } \\
\hline 15 & Nurrahmadina & Jawa \\
\hline 16 & Graceselya Mega FemberLbn. Gaol & Batak Toba \\
\hline 17 & Mayasari Apulina Lahagu & Nias \\
\hline 18 & Rut Klara Panesa Rumapea & Simalungun \\
\hline 19 & Melisa Silalahi & Batak Toba \\
\hline 20 & Meirin Sirait & Batak Toba \\
\hline 21 & Sahadatul Munawarah & Jawa \\
\hline 22 & Thessalonica Sinurat & Batak Toba \\
\hline 23 & Lastri Sihombing & Batak Toba \\
\hline
\end{tabular}

Table 3. Viola

\begin{tabular}{|c|l|l|}
\hline No. & \multicolumn{1}{|c|}{ Name } & \multicolumn{1}{c|}{ Ethnic } \\
\hline 24 & Pitaria Juneta Malau & Batak Toba \\
\hline 25 & Dedi & Batak toba \\
\hline 26 & Yoshua Ronaldo S & Batak Toba \\
\hline 27 & Risda Mayasari & Melayu \\
\hline 28 & Florence Trionita Sembiring & Karo \\
\hline
\end{tabular}

Table 4. Contra Bass

\begin{tabular}{|c|l|l|}
\hline No. & \multicolumn{1}{|c|}{ Name } & \multicolumn{1}{c|}{ Ethnic } \\
\hline 29 & Albesta Sembiring & Karo \\
\hline 30 & Bima & Batak toba \\
\hline
\end{tabular}

Table 5. Flute

\begin{tabular}{|c|l|l|}
\hline No. & \multicolumn{1}{|c|}{ Name } & \multicolumn{1}{c|}{ Ethnic } \\
\hline 31 & Rini Alicia Sirait & Bataktoba \\
\hline 32 & Christiani Hutagalung & Bataktoba \\
\hline 33 & Edriana Marbun & Bataktoba \\
\hline
\end{tabular}

Table 6. Klarinet

\begin{tabular}{|c|l|l|}
\hline No. & \multicolumn{1}{|c|}{ Name } & \multicolumn{1}{c|}{ Ethnic } \\
\hline 34 & Shinta Bella Sidabutar & Bataktoba \\
\hline 35 & Johannes Silitonga & Bataktoba \\
\hline
\end{tabular}

Table 7. Alto Saxophone

\begin{tabular}{|c|l|l|}
\hline No. & \multicolumn{1}{|c|}{ Name } & \multicolumn{1}{c|}{ Ethnic } \\
\hline 36 & Putra Dion Sianturi & Bataktoba \\
\hline 37 & Marianus Sihombing & Bataktoba \\
\hline
\end{tabular}

Table 8. Tenor Saxophone

\begin{tabular}{|c|l|l|}
\hline No. & \multicolumn{1}{|c|}{ Name } & \multicolumn{1}{c|}{ Ethnic } \\
\hline 38 & Jonathan Felix Peter Turnip & Bataktoba \\
\hline
\end{tabular}




\begin{tabular}{|l|l|l|}
\hline 39 & Daud & Bataktoba \\
\hline
\end{tabular}

Table 9. Baritone

\begin{tabular}{|c|l|l|}
\hline No. & \multicolumn{1}{c|}{ Name } & \multicolumn{1}{c|}{ Ethnic } \\
\hline 40 & M. Yusuf M.Sn & Karo \\
\hline
\end{tabular}

Table 10. Trumpet

\begin{tabular}{|c|l|l|}
\hline No. & \multicolumn{1}{|c|}{ Name } & \multicolumn{1}{c|}{ Ethnic } \\
\hline 41 & Dicky Ananda Putra & Jawa \\
\hline 42 & Filla Delpia & Karo \\
\hline 43 & Richard Tampak Ginting & Karo \\
\hline 44 & Ainun Erryaprina Hrp & Mandailing \\
\hline
\end{tabular}

Table 11. Combo

\begin{tabular}{|c|l|l|}
\hline No. & \multicolumn{1}{|c|}{ Name } & \multicolumn{1}{c|}{ Ethnic } \\
\hline 45 & Taufan RidhoNugraha & Jawa \\
\hline 46 & JeprynWaruwu & Nias \\
\hline 47 & Andrew Zendrato & Nias \\
\hline 48 & Reza Hardiansyah & Jawa \\
\hline 49 & Burhan & Batak Toba \\
\hline 50 & Evi Purnama Sari Nst. & Mandailing \\
\hline 51 & Yulia Trifena Simatupang & Batak Toba \\
\hline
\end{tabular}

Table 12. Timpani

\begin{tabular}{|c|l|l|}
\hline No. & \multicolumn{1}{c|}{ Ethnic } \\
\hline 52 & Libertus Waruwu & Nias \\
\hline
\end{tabular}

Table 13. Triangel

\begin{tabular}{|c|l|l|}
\hline No. & \multicolumn{1}{c|}{ Name } & \multicolumn{1}{c|}{ Ethnic } \\
\hline 53 & Mei Ari Putra & Batak Toba \\
\hline
\end{tabular}

Table 14. Choir

\begin{tabular}{|c|l|l|}
\hline No. & \multicolumn{1}{|c|}{ Name } & \multicolumn{1}{c|}{ Ethnic } \\
\hline 54 & Audri Natalia Simorangkir & Batak Toba \\
\hline 55 & Syahnaz Farsia Dahni & Aceh \\
\hline 56 & Dara Ari Gayoni & Gayo \\
\hline 57 & Mita Sazidani & Tamiang \\
\hline 58 & Silvia Elvyani & Batak Toba \\
\hline 59 & Stefanus Lbn. Gaol & Batak Toba \\
\hline 60 & Ivenna Nadia Silitonga & Batak Toba \\
\hline 61 & Wirem Multiani Siahaan & Batak Toba \\
\hline 62 & Alfiqri & Aceh \\
\hline 63 & Chindy Angelia Hutabarat & Batak Toba \\
\hline 64 & Melisa Krisdayanti Nainggolan & Batak Toba \\
\hline 65 & Sayuma & Batak Toba \\
\hline 66 & Fara Dhilla Dewantari & Jawa \\
\hline
\end{tabular}

From the ethnic backgrounds of students who take orchestra courses, they certainly have different characters, some are good and some are bad. But with the learning of the student 
character orchestra can be formed, from the bad to the good, remain on the good character or remain on the bad character, or the emergence of new characters. This can be seen in the following table:

Table 15. Different Characters

\begin{tabular}{|c|c|c|}
\hline No & Ethnic & Character \\
\hline 1 & Batak Toba & $\begin{array}{l}\text { 1. Gentle } \\
\text { 2. Faithful friend } \\
\text { 3. Uphold the value of customs } \\
\text { 4. Hard in educating children } \\
\text { 5. Great in politics } \\
\text { 6. Happy to socialize } \\
\text { 7. Respect for peerage } \\
\text { 8. Don't like to be underestimated }\end{array}$ \\
\hline 2 & Melayu & $\begin{array}{l}\text { 1. Tolerance } \\
\text { 2. Like friends } \\
\text { 3. Suave } \\
\text { 4. Understood Language } \\
\text { 5. Be patient } \\
\text { 6. Merciful } \\
\text { 7. Like to entertain } \\
\text { 8. Artistic } \\
\text { 9. High self-esteem }\end{array}$ \\
\hline 3 & Batak Karo & $\begin{array}{l}\text { 1. Stubborn } \\
\text { 2. Forgiving } \\
\text { 3. Friendly } \\
\text { 4. Weepy } \\
\text { 5. Be patient } \\
\text { 6. Jealousy } \\
\text { 7. Be diligent } \\
\text { 8. Nagging } \\
\text { 9. Merciful } \\
\text { 10. Understanding } \\
\text { 11. Aggressive } \\
\text { 12. Soft }\end{array}$ \\
\hline 4 & $\begin{array}{l}\text { Batak } \\
\text { Simalungun }\end{array}$ & $\begin{array}{l}\text { 1. Static life } \\
\text { 2. Consistent } \\
\text { 3. Sympathy } \\
\text { 4. Big hearted } \\
\text { 5. Good at hiding emotions } \\
\text { 6. Just the way they are } \\
\text { 7. Have lots of friends } \\
\text { 8. Quiet } \\
\text { 9. Observer } \\
\text { 10. Pessimistic }\end{array}$ \\
\hline 5 & $\begin{array}{l}\text { Batak Pak- } \\
\text { Pak }\end{array}$ & $\begin{array}{l}\text { 1. Socialize } \\
\text { 2. Fast familiar } \\
\text { 3. Easily influenced } \\
\text { 4. Easily irritated }\end{array}$ \\
\hline
\end{tabular}




\begin{tabular}{|c|c|c|}
\hline & & $\begin{array}{l}\text { 5. Not Consistent } \\
\text { 6. Faithful friend }\end{array}$ \\
\hline 6 & $\begin{array}{l}\text { Batak } \\
\text { Mandailing }\end{array}$ & $\begin{array}{l}\text { 1. Having a high social life } \\
\text { 2. Confidence } \\
\text { 3. Regarding one's own culture best } \\
\text { 4. Manners } \\
\text { 5. Stingy }\end{array}$ \\
\hline 7 & Nias & $\begin{array}{l}\text { 1. Like to work together and work together } \\
\text { 2. Love carrying owasa (big party) } \\
\text { 3. Highly respect guests } \\
\text { 4. Likes to be praised, flattered, and very self-respect } \\
\text { 5. Peace, community behavior that is full of love, harmony and peace } \\
\text { 6. Easily offended, in matters relating to elements of ethnicity and customs } \\
\text { 7. Obey the rules }\end{array}$ \\
\hline 8 & $\begin{array}{l}\text { Batak } \\
\text { Angkola }\end{array}$ & $\begin{array}{l}\text { 1. Merciful } \\
\text { 2. Good } \\
\text { 3. Fussy } \\
\text { 4. Calculation } \\
\text { 5. Judgment } \\
\text { 6. Faithful } \\
\text { 7. Independent } \\
\text { 8. Courageous } \\
\text { 9. Crybaby }\end{array}$ \\
\hline
\end{tabular}

The term character is actually neutral, negative or positive, bad or even good. The character referred to here is a good character called the formation or education of good or positive character. The following are positive and negative character categories from the ethnic groups in North Sumatra:

Table 16. Positive and Negative Character Categories

\begin{tabular}{|l|l|}
\hline \multicolumn{1}{|c|}{ Positive Character } & \multicolumn{1}{c|}{ Negative Character } \\
\hline 1. Be gentle & 1. Stubborn \\
2. Faithful friend & 2. Weepy \\
3. Uphold the value of customs & 3. Jealousy \\
4. Hard in educating children & 4. Fussy \\
5. Great in politics & 5. Pessimistic \\
6. Happy to socialize & 6. Easily influenced \\
7. Respect for peerage & 7. Easily offended \\
8. Don't like to be underestimated & 8. Not Consistent \\
9. Tolerance & 9. Stingy \\
10. Like friends & 10. Considers own culture best \\
11. Suave & 11. Easily offended, in matters relating to \\
12. Be virtuous & elements of ethnicity and customs \\
13. Patience & 12. Stingy \\
14. Merciful & 13. Judgment \\
15. Likes to entertain & \\
16. Artistic & \\
17. High self-esteem & \\
18. Forgiving & \\
19. Friendly & \\
\hline
\end{tabular}


20. Patience

21. Be diligent

22. Merciful

23. Understanding

24. Aggressive

25. Soft

26. Static life

27. Consistent

28. Sympathy

29. Big hearted

30. Clever emotions

31. Just the way they are

32. Have lots of friends

33. Quiet

34. Observer

35. Socializing

36. Get familiar quickly

37. Loyal friend

38.Has a high social life

39. Confidence

40. Manners

41. Likes to work together and work together

42. Have fun owasa (big party)

43. Highly respect guests

44. Liked to be praised, flattered, and very selfrespect

45. Like peace, the behavior of people who are loving, harmonious and peaceful

46. Obey the rules

47. Merciful

48. Good

49. Faithful

50. Independent

51. Brave

From the characters described in the table above, there are positive and negative characters. But with the learning of orchestras in Music Education Study Program, the character of students will be able to change, from negative to positive or remain positive. This shows very good learning in orchestra courses because it can form the character of students well.

\section{Conclusion}

The conclusion of this research is through orchestral learning it turns out to be able to shape student characters, and can change these characters into better characters. Therefore each course must be adjusted to the characteristics of the course. 


\section{References}

Amstrong. (2013). Kecerdasan Multipel di Dalam Kelas. Issue 3. Jakarta: PT Indeks

Ardan, A., S . (2016). The Development of Biology Teaching Material Based on the Local Wisdom of Timorese to Improve Students Knowledge and Attitude of Environment in Caring the Preservation of Environment. International Journal of Higher Education, v5 n3 p190-200 2016

Afandi. (2018). Stimulasi Keterampilan Berpikitr Tingkat Tinggi, Semarang: UNS Press

Dewi, Izwita., Harahap, Muhammad Syahri, (2016). The Development of Geometri Teaching Materials Based on Constructivism to Improve the Students' Mathematic Reasoning Ability through Cooperative Learing Jigsaw at the Class VIII of SMP Negeri 3 Padangsidimpuan. Journal of Education and Practice, v7 n29 p68-82 2016

Eren, K., Yagbasan, O. (2017). Development of Teaching Materials Based on Geographical Information Systems: An Example on Symbolic Sites in Turkey. International Journal of Curriculum and Instruction, v9 n1 p31-46 2017

Ika, L. (2013). Pengembangan Bahan Ajar Berbasis Kompetensi. Padang:Akademia Permata. Jasmine, J. (2012). Metode Mengajar Multiple Intelegences. Bandung: Nuansa

Koesnandar. (2008). Modul Pemanfaatan TIK untuk Pembelajaran. Jakarta: Pusat Teknologi Informasi dan Komunikasi Pendidikan

Pono, B. (2003). Pengantar Pengetahuan Harmoni, Yogyakarta: Karnisius,

Skandarwassid., Suhendar, D. (2011). Strategi Pembelajaran Bahasa. Bandung : PT Remaja Rosdakarya

Sani, R. (2019). Pembelajaran Berbasis HOTS. Jakarta: TS Smart

Trianto. (2012). Mendesain Model Pembelajaran Inovatis- Progresif. Jakarta: Kencana 